\title{
Changes in the content of free phenolic acids and antioxidative capacity of wholemeal bread in relation to cereal species and fermentation type
}

\author{
Marta Skrajda-Brdak ${ }^{1}$ (D - Iwona Konopka ${ }^{1} \cdot$ Małgorzata Tańska $^{1} \cdot$ Sylwester Czaplicki ${ }^{1}$
}

Received: 21 May 2019 / Revised: 29 June 2019 / Accepted: 6 July 2019 / Published online: 19 July 2019

(c) The Author(s) 2019

\begin{abstract}
Only low molecular, simple phenolic acids and their dimers can be easily absorbed by intestinal cells. In this study, the changes in free (unbound) phenolic acids and antioxidative capacity were tracked from flour, through bread to final in vitro bread hydrolysate. The initial material of the study included wholemeal flours made of common wheat, spelt wheat and rye, fermented with baker's yeast Saccharomyces cerevisiae or by the use of baking starter made of lactic acid bacteria Lactobacillus casei and L. brevis cultures with $S$. chevalieri yeast. A significant overall increase in free phenolic acids in breads and their hydrolysates was found, with the highest increase found for rye samples. The impact of the fermentation type was not consistent, showing additional crucial factors of used flours, which can affect final results. The free phenolic acid content in all the samples was correlated with the antioxidant capacity.
\end{abstract}

Keywords Dough fermentation · Bread · Free phenolic compounds $\cdot$ Ferulic acid · Antioxidative capacity $\cdot$ In vitro digestion

\section{Introduction}

Bread is a staple food in western countries despite the fact that over the past few decades its consumption has fallen significantly. Current consumption ranges from ca. $100 \mathrm{~g} /$ day (ca. 2-3 slices) in the UK, Italy, Denmark and Germany [1-3] to ca. $150 \mathrm{~g}$ a day in Poland [4]. Despite a relatively small share in the diet, it still contributes more than $10 \%$ of adults' daily intake of protein, thiamine, niacin, folate, iron, zinc, copper, and magnesium; one-fifth of fibre and calcium intakes; and more than one-quarter of manganese intake [3]. In addition to this, bread, especially made of wholemeal flour, is a source of low molecular health-promoting compounds such as sterols, tocols, alkylresorcinols, and phenolic compounds. Among them, phenolic acids are the most abundant, but their overall content is highly variable according to grain species (common wheat, spelt wheat, rye, etc.), grain

Marta Skrajda-Brdak

marta.skrajda@uwm.edu.pl

1 Chair of Plant Food Chemistry and Processing, Faculty of Food Sciences, University of Warmia and Mazury in Olsztyn, Pl. Cieszyński 1, 10-726 Olsztyn, Poland cultivar, condition of cultivation as well as the type of used flour (wholemeal vs. white flour) [5-7]. As a result, white breads contain only ca. $14 \mu \mathrm{g} / \mathrm{g}$, while wholemeal breads contain up to $1400 \mu \mathrm{g} / \mathrm{g}$ of phenolic acids in dry matter [8]. Considering that the daily intake of phenolic compounds assayed, for example, in a typical American diet is close to $1000 \mathrm{mg}$ [9], wholemeal bread significantly contributes to this intake.

The health benefits of phenolic acids are primarily associated with their antioxidant properties, but these acids also show anti-ulcer, anti-diabetic, anti-cancer, anti-inflammatory, anti-aging, anti-microbial, cardioprotective, hepatoprotective and neuroprotective activities [10,11]. The majority of these activities have phenolic compounds which reach systemic circulation [12]. Hydroxycinnamic acids (e.g., ferulic) are especially quickly absorbed from gastrointestinal tract (from stomach, jejunum, ileum and colon) and are detectable, for example, within $10 \mathrm{~min}$ in human blood plasma after oral administration [13]. However, only a small amount of cereal phenolic acids are easily accessible from the digestive tract since the majority (up to 99\%) exist as esters, ethers and amides with other grain components (especially with arabinoxylans) and they create a lignocellulose matrix resistant to digestion $[13,14]$. Only relatively low 
molecular, simple phenolic acids and their derivatives (like dimers of ferulic acid) can be absorbed by the intestinal cells, which exhibit intracellular phenolic acid esterase activity and, which increases the amount of phenolics accessible in the upper gastrointestinal tract $[15,16]$.

The options of increasing the content of easily accessible phenolic acids in cereal products have been investigated by many researchers. In general, reduction of the size of bran particles or microfluidization promotes the liberation of free phenolic acids from cereal grain products during processing and digestion $[17,18]$. A significant increase in their content was also observed when grain was germinated [19]. The use of arabinoxylan-degrading enzymes, fermentation processes, or both, also produce enhanced amounts of free phenolic acids. For example, wheat bran fermentation with yeast combined with enzyme treatment (cell wall degrading enzymes: mainly xylanase, cellulase, $\beta$-glucanase and feruloyl esterase) for $20 \mathrm{~h}$ at $20^{\circ} \mathrm{C}$ led to a ca. fourfold increase in free ferulic acid level [20]. Similarly, Turner et al. [21] revealed that the use of the commercial Ultraflo $L$ preparation containing feruloyl esterase (from Humicola insolens) increased the free ferulic acid content of wheat grain samples five-sixfold. Konopka et al. [5] observed that the use of commercial baking starter LV1 SAF Levain for the preparation of wheat and rye sourdough bread increased the content of free ferulic acid up to $13.5 \%$ of total bound ferulic acid. In the cited study, the highest increase was noted in bread made from wholemeal rye flour. Bacteria strains of this baking starter (L. casei and L. brevis) have a lower ability to decompose free phenolic acids. In contrast, a significantly reduced content of free phenolic acids was determined in breads produced using sourdough composed of a mixture of L. plantarum E-78076 + L. brevis E-95612 + Candida milleri C-96250 [22] or of L. plantarum TMW 1460 and $L$. hammesii DSM 16381 [23]. In these sourdoughs (both rye and wheat), monomeric phenolic acids were converted to various vinyl and ethyl-derivatives.

As previously mentioned, the health-promoting functionality of phenolic acids results from their antioxidant properties. These properties are usually determined in extracts made using aqueous organic solvents (like alcohol-water mixtures). However, Delgado-Andrade et al. [24] stated that the use of the in vitro digestion of bread is a critical stage that allows the release of a large amount of compounds with antioxidant properties. The cited authors found the antioxidant capacity of these extracts from oral and gastric digestion stages might be more useful for nutritional purposes than the values determined in aqueous organic extracts. However, to date, the results of the antioxidant capacity of various breads are still scarce and generally not consistent.

The aim of the present study was to compare the impact of selected types of wholemeal breads (made of common wheat, spelt wheat, and rye flours), produced under the impact of two methods of dough fermentation (using baker's yeast or sourdough followed by baker's yeast) and simulated bread digestion (in vitro assay) on the changes of free phenolic acid contents and antioxidative capacity using ORAC and DPPH tests, respectively. These changes were tracked from flour, through bread-to-bread digestion product.

\section{Materials and methods}

\section{Materials}

Three commercial wholemeal flours [common wheat (CWF), spelt (CSF) and rye (CRF)] and laboratory-prepared wholemeal flour (LWF) of Opatka cv. (common wheat) were used in this study. Grain of Opatka cv. was ground into flour in a Falling Number 3100 mill. The basic quality characteristics of the used flours are presented in Table 1. The moisture content was determined based on PN-EN ISO 712:2012 [25] method and ash content according to ICC method 104/1, ICC 1990 [26]. The falling number was determined in a Falling Number Apparatus 1600 (Petren, Sweden) according to Standard PN-EN ISO 3093:2010 [27]. An amylograph test was conducted in a Brabender amylograph (type 800145) according to Standard PN-EN ISO 7973:2016-01 [28]. The content of wet gluten was determined according to PN-EN ISO 21415-2:2015 [29] on the gluten testing line type SZ-1 (ZBPP Sp. z o.o., Bydgoszcz, Poland). The pH was determined on-line by a HI $9125 \mathrm{pH}$-meter, equipped with an HI 1083B electrode (Hanna Instruments, Cluji-Napoca, Romania). Titratable acidity (TTA) was determined according to Koistinen et al. [22]. The baker's yeast $S$. cerevisiae, the baking starter LV1 SAF Levain containing a mixture of $L$. casei and $L$. brevis cultures ( $2 \%$ in total) with $S$. chevalieri yeast (98\%) and commercial flours were purchased from a local market in Olsztyn.

\section{Wheat bread making process}

Preparation involved dough preparation and baking a total of four variants of bread. Their formulations are shown in Table 2. Briefly, to obtain sourdough, a $1 \%$ concentration of baking starter relative to the total flour weight was used. Sourdough was prepared with a yield of $200 \%$ (175 g of flour and $175 \mathrm{~g}$ of water). These ingredients were carefully mixed, then allowed to ferment for $24 \mathrm{~h}$ at $30{ }^{\circ} \mathrm{C}$ with continuous mixing using a laboratory water bath shaker (357 type; Elpan, Lubawa, Poland). Bread dough was prepared by adding the rest of the flour and water (according to dough sample variants), salt and yeast. Dough was kneaded using a laboratory dough kneading machine (GM-2; Bydgoszcz, Poland) for $5 \mathrm{~min}$. The fermentation process was performed using a proofing chamber (PL 10 type; Warmia, Grudziądz, 
Table 1 Main characteristics of used cereal flours and prepared sourdoughs
Table 2 Formulations of prepared breads

\begin{tabular}{|c|c|c|c|c|}
\hline & \multicolumn{4}{|c|}{ Wholemeal flour } \\
\hline & LWF & CWF & CSF & $\mathrm{CRF}$ \\
\hline Moisture content (\%) & $12.37 \mathrm{~b}$ & $12.52 \mathrm{a}$ & $11.74 \mathrm{c}$ & $12.52 \mathrm{a}$ \\
\hline Ash content $(\%)$ & $1.91 \mathrm{~d}$ & $1.97 \mathrm{a}$ & $1.94 \mathrm{bc}$ & $1.92 \mathrm{c}$ \\
\hline Falling number value (s) & $415 \mathrm{a}$ & $259 \mathrm{c}$ & $346 \mathrm{~b}$ & $207 \mathrm{~d}$ \\
\hline Wet gluten content $(\%)$ & $8.87 \mathrm{c}$ & $24.48 \mathrm{~b}$ & $29.21 \mathrm{a}$ & n.a. \\
\hline Amylograph viscosity (BU) & $930 \mathrm{a}$ & $181 \mathrm{~d}$ & $658 \mathrm{~b}$ & $395 \mathrm{c}$ \\
\hline Initial temperature of gelation $\left({ }^{\circ} \mathrm{C}\right)$ & $60 \mathrm{c}$ & $63 \mathrm{bc}$ & $64.5 \mathrm{a}$ & $54.5 \mathrm{~d}$ \\
\hline Final temperature of gelation $\left({ }^{\circ} \mathrm{C}\right)$ & $87 \mathrm{a}$ & $78 \mathrm{c}$ & $83.3 \mathrm{bc}$ & $65 \mathrm{~d}$ \\
\hline Titratable acidity (mL of $0.1 \mathrm{M} \mathrm{NaOH} / 10 \mathrm{~g}$ of flour) & $6.75 \mathrm{c}$ & $3.25 \mathrm{~d}$ & $7.95 \mathrm{a}$ & $7.55 \mathrm{~b}$ \\
\hline Sourdough $\mathrm{pH}$ & $4.57 \mathrm{~b}$ & $4.44 \mathrm{c}$ & $4.60 \mathrm{~b}$ & $5.21 \mathrm{a}$ \\
\hline $\begin{array}{l}\text { Sourdough titratable acidity ( } \mathrm{mL} \text { of } 0.1 \mathrm{M} \mathrm{NaOH} / 10 \mathrm{~g} \text { of } \\
\text { sourdough) }\end{array}$ & $21.76 \mathrm{~b}$ & $17.07 \mathrm{c}$ & $22.40 \mathrm{a}$ & $15.05 d$ \\
\hline
\end{tabular}

n.a. not analysed; different letters in the same line indicate statistically significant differences $(P \leq 0.05)$, obtained by the ANOVA with Duncan test $(n=3)$

\begin{tabular}{lllrlrrl}
\hline Variant & Type of flour & Flour $(\mathrm{g})$ & Yeast $(\mathrm{g})$ & Sordough $(\mathrm{g})$ & Salt $(\mathrm{g})$ & Water $(\mathrm{g})$ & $\begin{array}{l}\text { Dough } \\
\text { yield } \\
(\%)\end{array}$ \\
\hline 1 & LWF, CWF, CSF & 350 & 10.5 & - & 3.5 & 192.5 & 155 \\
2 & LWF, CWF, CSF & 175 & 3.5 & 175 & & 17.5 & \\
3 & CRF & 350 & 10.5 & - & 202.5 & 165 \\
4 & CRF & 175 & 3.5 & 175 & 27.5 & \\
\hline
\end{tabular}

Poland). Breads from wheat flour (wheat 1, wheat 2, spelt) were fermented for a total of $110 \mathrm{~min}$ in a $85 \pm 2 \%$ relative humidity and $31^{\circ} \mathrm{C}$. After $80 \mathrm{~min}$, dough was mixed for $1 \mathrm{~min}$ and fermented for another $30 \mathrm{~min}$. In turn, rye breads were fermented for $60 \mathrm{~min}$ at a $85 \pm 2 \%$ relative humidity at $35{ }^{\circ} \mathrm{C}$. Finally, $250 \mathrm{~g}$ samples of wheat dough and $350 \mathrm{~g}$ samples of rye dough were manually sheeted and rolled, proofed up to an optimum volume increase, then baked (230 ${ }^{\circ} \mathrm{C}, 30 \mathrm{~min}$ ) in an electric oven (PL 10 type; Warmia).

Cooled bread was manually divided into crust and crumb. Separated crumb was subsequently lyophilized (Hetosicc freeze dryer Cd 13-2-type; Heto, Birkerod, Denmark). All lyophilisates were ground (laboratory mill type A 10; IKA Labortechnik, Staufen, Germany) and stored at $-20 \pm 2{ }^{\circ} \mathrm{C}$ until further use (not longer than 2 months).

\section{In vitro digestion}

\section{Reagents}

Simulated salivary fluid (SSF), simulated gastric fluid (SGF) and simulated intestinal fluid (SIF) were prepared according to Minekus et al. [30] (Table 3). To adjust $\mathrm{pH}$ to needed values, $\mathrm{HCl}(6 \mathrm{~mol} / \mathrm{L})$ and $\mathrm{NaOH}(1 \mathrm{~mol} / \mathrm{L})$
Table 3 Preparation of digestion fluids stock solutions (made up to the volume $200 \mathrm{~mL}$ )

\begin{tabular}{lllll}
\hline Constituent & $\begin{array}{l}\text { Stock con- } \\
\text { centration } \\
(\mathrm{mol} / \mathrm{L})\end{array}$ & $\begin{array}{l}\text { SSF } \\
\mathrm{pH} \mathrm{7}\end{array}$ & $\begin{array}{l}\text { SGF } \\
\text { VH 3 }\end{array}$ & $\begin{array}{l}\text { SIF } \\
\text { vH 7 }\end{array}$ \\
\hline $\mathrm{KCL}$ & 0.5 & 7.55 & 3.45 & 3.4 \\
$\mathrm{KH}_{2} \mathrm{PO}_{4}$ & 0.5 & 1.85 & 0.45 & 0.4 \\
$\mathrm{NAHCO}_{3}$ & 1 & 3.4 & 6.25 & 21.25 \\
$\mathrm{NaCl}$ & 2 & - & 5.9 & 4.8 \\
$\mathrm{MgCl}_{2}\left(\mathrm{H}_{2} \mathrm{O}\right)_{6}$ & 0.15 & 0.25 & 0.2 & 0.55 \\
$\left(\mathrm{NH}_{4}\right)_{2} \mathrm{CO}_{3}$ & 0.5 & 0.03 & 0.25 & - \\
\hline
\end{tabular}

were used. $\alpha$-Amylase (type IX-A, Sigma-Aldrich) was mixed with SSF to achieve $150 \mathrm{U} / \mathrm{mL}$. Pepsin solution (porcine gastric mucosa, 3200-4500 U/mg protein, SigmaAldrich) made up with SGF to achieve a 25,000 U/mL solution. Pancreatin (from porcine pancreas, $4 \times \mathrm{USP}$, Sigma-Aldrich) was mixed with SIF to achieve an $800 \mathrm{U} /$ mL solution. Bile salts (porcine, Sigma-Aldrich) made up with SIF, $60 \mathrm{mg} / \mathrm{mL}$. 


\section{Simulated in vitro digestion method}

Lyophilized breads were subjected to digestion according to the method described by Minekus et al. [30]. In the oral phase, $5 \mathrm{~g}$ of grounded sample was mixed with $3.5 \mathrm{~mL}$ simulated salivary fluid, $0.5 \mathrm{~mL} \alpha$-amylase solution (type IX-A, Sigma-Aldrich), $25 \mu \mathrm{L} 0.3 \mathrm{M} \mathrm{CaCl}_{2}$ and $975 \mu \mathrm{L}$ of water. After $2 \mathrm{~min}$, the following were added to the bolus: $7.5 \mathrm{~mL}$ of simulated gastric fluid, $1.6 \mathrm{~mL}$ of pepsin solution (Sigma-Aldrich), $5 \mu \mathrm{L}$ of $0.3 \mathrm{M} \mathrm{CaCl}_{2}, 1 \mathrm{M} \mathrm{HCl}$ (to achieve $\mathrm{pH}$ 3.0) and water to obtain $10 \mathrm{~mL}$ of total added fluids at this stage. Digestion occurred in a shaking incubator (IncuShaker Mini, Benchmark, Sayreville, NJ, USA) for $2 \mathrm{~h}$ at $37^{\circ} \mathrm{C}$. After gastric phase reagents were added to start the intestinal phase, the following were added to the chyme: $11 \mathrm{~mL}$ of simulated intestinal fluid, $5 \mathrm{~mL}$ of pancreatin solution, $2.5 \mathrm{~mL}$ of bile salt solution, $0.15 \mathrm{~mL}$ of $0.3 \mathrm{M} \mathrm{CaCl}_{2}$, $1 \mathrm{M} \mathrm{NaOH}$ (to achieve pH 7.0) and water to obtain $20 \mathrm{~mL}$ of total added fluids at this stage. The intestinal digestion was conducted in the shaking incubator for $2 \mathrm{~h}$ in $37^{\circ} \mathrm{C}$. Immediately after digestion, the samples were snap-frozen using liquid nitrogen and then lyophilized. After lyophilisation, the samples were grounded and used for further analysis.

\section{Determination of phenolic acid content}

The phenolic acids were determined by the RP-HPLC technique according to the method described by SkrajdaBrdak et al. [31]. The extraction of free phenolic acids was performed in triple, by adding to $1 \mathrm{~g}$ of finely milled grain $10 \mathrm{~mL}$ of $80 \%$ methanol and sonication for $15 \mathrm{~min}$ using an ultrasonic bath (InterSonic, Olsztyn, Poland). After extraction samples were centrifuged in Eppendorf centrifuge, type 5810R (Eppendorf, Hamburg, Germany). Supernatants were collected and evaporated to dryness at temperatures below $50{ }^{\circ} \mathrm{C}$ in a vacuum evaporator (Büchi, type R-210; Büchi Labortechnik, Flawil, Switzerland). The residue was dissolved in $30 \mathrm{~mL}$ of deionized water acidified to $\mathrm{pH} 2$. Phenolic acids were extracted by fourfold extraction with $20 \mathrm{~mL}$ of ethyl acetate. Total phenolic acids were extracted after $4 \mathrm{~h}$ alkaline hydrolysis, which was performed by adding to $0.5 \mathrm{~g}$ of finely milled grain 30 $\mathrm{mL}$ of $2 \mathrm{~mol} \mathrm{NaOH}$ and mixing. After that time samples were acidified to $\mathrm{pH} \mathrm{2,} \mathrm{with} 6 \mathrm{~mol} \mathrm{HCl}$. Samples were centrifuged and supernatants were subjected to extraction of total phenolic acids fourfold with $30 \mathrm{~mL}$ of ethyl acetate. Collected ethyl acetate extracts were evaporated in a vacuum evaporator, re-dissolved in $1 \mathrm{~mL}$ of methanol and subjected to chromatographic separation. Chromatographic separation was performed on an Agilent Technologies (Santa Clara, USA) 1200 series system fitted out with a photodiode detector with a Waters XBridge $\mathrm{C} 18$ column (Milford, MA, USA) $(150 \mathrm{~mm} \times 2.1 \mathrm{~mm}, 3.5 \mu \mathrm{m})$ at $30{ }^{\circ} \mathrm{C}$.
A gradient elution program was employed, using water/ formic acid $(99.85 / 0.15, \mathrm{v} / \mathrm{v})$ (solvent A) and acetonitrile/ formic acid $(99.85 / 0.15, \mathrm{v} / \mathrm{v})$ (solvent B) as elution solvents. The flow rate was $0.5 \mathrm{~mL} / \mathrm{min}$ with a $40 \mathrm{~min}$ gradient elution program as follows: $0-3 \mathrm{~min} 1 \% \mathrm{~B} ; 3-15 \mathrm{~min}$, 1-10\% B; 15-25 min, 10-60\% B; 25-27 min, 60-80\% B; 27-30 min, $80 \%$ B; 30-33 min, 80-1\% B and was stable until $40 \mathrm{~min}$. The detection was performed at the wavelength of 260 ( $p$-OH-benzoic, vanillic, syringic acid) and $320 \mathrm{~nm}$ ( $p$-coumaric, ferulic, sinapic acid). Phenolic acids were identified by comparison with absorption spectra of the reference phenolic acids (Sigma-Aldrich, Saint Louis, USA). The content of phenolic acids was determined from calibration curves of reference standards and expressed as $\mu \mathrm{g}$ per $1 \mathrm{~g}$ of a sample dry mass $(\mathrm{DM})$. The $R^{2}$ value for all identified phenolic acids was $\geq 0.9988$. Phenolic acid recovery was in range of $91-99 \%$. The LOD for $p-\mathrm{OH}-$ benzoic, vanillic, syringic acid was $0.05 \mu \mathrm{g} / \mathrm{mL}$, while for $p$-coumaric, ferulic and sinapic acid was $0.025 \mu \mathrm{g} / \mathrm{mL}$. The LOQ for $p$-OH-benzoic, vanillic, syringic acid was $0.17 \mu \mathrm{g} / \mathrm{mL}$, while for $p$-coumaric, ferulic and sinapic acid was $0.08 \mu \mathrm{g} / \mathrm{mL}$. Calculated accuracy was as follows: p-OH-benzoic acid-102.33\%, vanillic acid-102.44\%, syringic acid $101.60 \%, p$-coumaric acid- $104.59 \%$, ferulic acid- $102.72 \%$ and sinapic acid $107.99 \%$.

\section{Preparation of extracts from flour, bread and in vitro bread hydrolysate}

Finely milled samples $(0.2 \mathrm{~g})$ were triple-extracted with $80 \%$ methanol $(1.5 \mathrm{~mL})$ and centrifuged. Supernatants were collected, then evaporated to dryness at temperatures below $50{ }^{\circ} \mathrm{C}$ in a vacuum evaporator. The residue was dissolved in $1 \mathrm{~mL}$ of methanol and used to determine the antioxidant potential.

\section{DPPH}

The antioxidant capacity of samples was determined by the DPPH Radical Scavenging Assay, according to Konopka et al. [32] with some modifications. The extracts were added to a DPPH (2,2-diphenyl-1-picrylhydrazyl) solution $(0.2 \mathrm{mmol} / \mathrm{L}$ in methanol $)$ and the mixture was shaken and incubated in the dark at room temperature for $30 \mathrm{~min}$. Absorbance was measured at $517 \mathrm{~nm}$ against methanol using a FLUOstar Omega multi-mode microplate reader (BMG LABTECH, Offenburg, Germany). The antioxidant capacity was determined based on a curve of \% DPPH radical scavenging activity of different Trolox concentrations in methanol and expressed as $\mu \mathrm{M}$ TE (Trolox Equivalent) per $1 \mathrm{~g}$ of sample DM. 


\section{ORAC}

The ORAC test was carried out according to the method described by Huang et al. [33] with some modifications. The assay was performed using the FLUOstar Omega multimode microplate reader. $25 \mu \mathrm{L}$ of extracts and pure solvent (blank sample) were placed in wells of a black 96-well plate with $150 \mu \mathrm{L}$ of $10 \mathrm{nM}$ fluorescein (in $75 \mathrm{mM}$ phosphate buffer, $\mathrm{pH}$ 7.4). The plate was pre-incubated at $37{ }^{\circ} \mathrm{C}$ for $15 \mathrm{~min}$, and $25 \mu \mathrm{L}$ of $153 \mathrm{mM}$ AAPH (2,2'-azobis-(2-methylpropionamidine) dihydrochloride, in $75 \mathrm{mM}$ phosphate buffer, pH 7.4) was added to each well. The fluorescence intensity was measured automatically by the reader (excitation at $485 \mathrm{~nm}$, emission at $540 \mathrm{~nm}$ ) every $1 \mathrm{~min}$ for $6 \mathrm{~h}$. The ORAC values were calculated using the differences of areas under the curves of fluorescence decay between the blank and sample (net area under the curve). Trolox was used as a standard. The results are expressed as $\mu \mathrm{M}$ TE per $1 \mathrm{~g}$ of sample DM.

\section{Statistical analysis}

All chemical analyses were done in triplicate and analysed using Statistica 13.0 PL software (StatSoft, Kraków, Poland) at a significance level of $P \leq 0.05$. The differences in sample phenolic acid compositions and antioxidant potential were determined using ANOVA with a Duncan test. Additionally, the Pearson's correlation coefficient was measured to determine the relationship between antioxidant potential and phenolic acids.

\section{Results and discussion}

\section{Total and free phenolic acids in used flours}

The total phenolic acid content varied among tested wholemeal wheat flours and reached values from $268 \mu \mathrm{g} / \mathrm{g}$ DM in flour of CSF to $430 \mu \mathrm{g} / \mathrm{g} \mathrm{DM}$ in flour of LWF (Table 4). These contents were rather low, since the HEALTHGRAIN project value determined for wheat grain ranges from 326-1171 $\mu \mathrm{g} / \mathrm{g}$ DM [34]. Similarly, wholemeal rye flour contained $422 \mu \mathrm{g} / \mathrm{g}$ DM of phenolic acids, and this value was below the range of 491-1082 $\mu \mathrm{g} / \mathrm{g}$ DM determined for rye grain [35]. However, it is worth knowing that the minimal concentration of phenolic acids determined in other studies is close to $200 \mu \mathrm{g} / \mathrm{g} \mathrm{DM}[31,36]$, while the highest concentration is close to $3200 \mu \mathrm{g} / \mathrm{g} \mathrm{DM}$ in wheat grain [37] and to $2400 \mu \mathrm{g} / \mathrm{g} \mathrm{DM}$ in rye grain [38]. The highest values were found in grain from biotic stresses during plant cultivation [7].

The phenolic acid fraction was composed of six phenolic acids (Table 4). Among them ferulic acid prevailed, reaching
Table 4 Total and free phenolic acids content in flours used in the study ( $\mu \mathrm{g} / \mathrm{g}$ of dry matter)

\begin{tabular}{|c|c|c|c|c|}
\hline & \multicolumn{4}{|l|}{ Flour } \\
\hline & LWF & CWF & CSF & $\mathrm{CRF}$ \\
\hline \multicolumn{5}{|l|}{ Free phenolic acids } \\
\hline$p$-OH benzoic & $0.30 \mathrm{~b}$ & $0.30 \mathrm{~b}$ & $0.26 \mathrm{c}$ & $0.32 \mathrm{a}$ \\
\hline Vanilic & $0.71 \mathrm{c}$ & $1.25 \mathrm{a}$ & $1.17 \mathrm{ab}$ & $1.14 \mathrm{~b}$ \\
\hline Syringic & n.d. & $1.30 \mathrm{a}$ & $0.78 \mathrm{~b}$ & n.d. \\
\hline$p$-Coumaric & $0.95 \mathrm{a}$ & $0.36 \mathrm{~b}$ & $0.19 \mathrm{c}$ & $0.91 \mathrm{a}$ \\
\hline Ferulic & $0.55 \mathrm{~d}$ & $1.38 \mathrm{c}$ & $1.98 \mathrm{~b}$ & $3.10 \mathrm{a}$ \\
\hline Sinapic & $0.12 d$ & $0.60 \mathrm{~b}$ & $0.36 \mathrm{c}$ & $1.73 \mathrm{a}$ \\
\hline \multicolumn{5}{|l|}{ Total phenolic acids } \\
\hline$p$-OH benzoic & $10.57 \mathrm{a}$ & $2.73 c$ & $3.24 \mathrm{~b}$ & $2.79 \mathrm{c}$ \\
\hline Vanilic & $19.82 \mathrm{a}$ & $6.20 \mathrm{~b}$ & $6.31 \mathrm{~b}$ & $6.89 \mathrm{~b}$ \\
\hline Syringic & n.d. & $6.45 \mathrm{a}$ & $4.99 \mathrm{~b}$ & n.d. \\
\hline$p$-Coumaric & $95.19 \mathrm{a}$ & $8.32 \mathrm{c}$ & $8.84 \mathrm{c}$ & $30.26 b$ \\
\hline Ferulic & $281.75 b$ & $222.1 \mathrm{c}$ & $221.77 \mathrm{c}$ & $332.26 \mathrm{a}$ \\
\hline Sinapic & $22.93 c$ & $27.49 b$ & $22.54 \mathrm{c}$ & $49.36 \mathrm{a}$ \\
\hline Sum of total phenolic acids & $430.26 \mathrm{a}$ & $273.29 b$ & $267.7 \mathrm{~b}$ & $421.56 a$ \\
\hline
\end{tabular}

Different letters in the same line indicate statistically significant differences $(P \leq 0.05)$, obtained by the ANOVA with Duncan test $(n=3) ; n . d$. not detected

a share from $79 \%$ (rye) to $83 \%$ (spelt). This acid was followed by ca. 3-22\% and 5-12\% shares of $p$-coumaric and sinapic acids, respectively, accompanied by a ca. 5-7\% share of sum of benzoic acids ( $p$-OH benzoic, vanillic and syringic) in wheat flours and a ca. $2 \%$ share of $p$-OH benzoic and vanillic acids in rye flour. A similar composition of phenolic acids in wheat and rye grain was previously found by other studies [31, 38, 39].

Only a small part of these compounds existed in an unbound (free) state. The content of free phenolic acids varied from $2.63 \mu \mathrm{g} / \mathrm{g}$ DM (LWF) to $7.24 \mu \mathrm{g} / \mathrm{g}$ DM (CRF) (Fig. 1), representing from 0.5 to $1.9 \%$ of total phenolic acids, respectively. In comparison, the free phenolic acid fraction in bread wheat grain can range from 3.1 to $6.7 \mu \mathrm{g} / \mathrm{g}$, with an average value of $4.2 \mu \mathrm{g} / \mathrm{g}$ [40], while in spelt grain this value can be close to $21 \mu \mathrm{g} / \mathrm{g}$ [31]. In rye flour, ferulic and sinapic acids had the highest share among free phenolic acids. For wheat flours, the shares of individual phenolic acids were highly variable. Free syringic acid was absent in LWF and rye flours.

\section{Free phenolic acids in breads and their in vitro hydrolysates}

The free phenolic acid content in breads varied from $9.21 \mu \mathrm{g} / \mathrm{g}$ DM in sourdough fermented bread of LWF to $50.09 \mu \mathrm{g} / \mathrm{g}$ DM in sourdough fermented rye bread (Fig. 1). The increase of free phenolic acids in relation to initial 
Fig. 1 Content of free phenolic acids in flours, breads, and breads hydrolysates

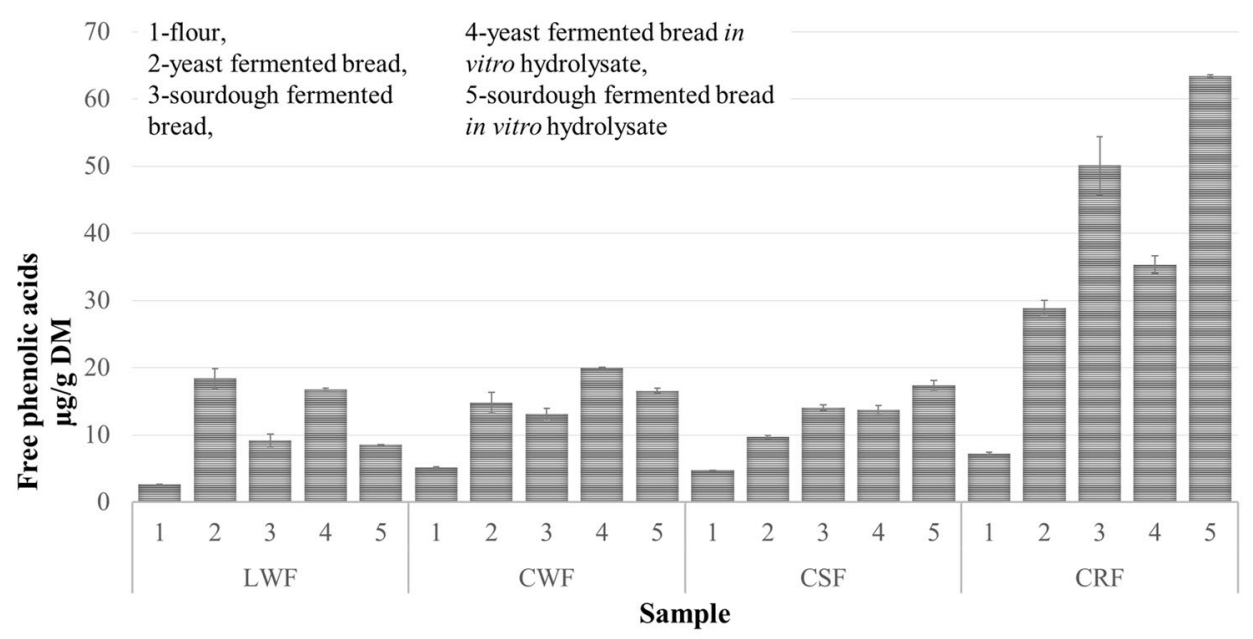

Table 5 Free phenolic acids content in breads ( $\mu \mathrm{g} / \mathrm{g}$ of dry matter)

\begin{tabular}{|c|c|c|c|c|}
\hline & \multicolumn{4}{|l|}{ Bread } \\
\hline & LWF & CWF & CSF & $\mathrm{CRF}$ \\
\hline \multicolumn{5}{|c|}{ Yeast fermented bread } \\
\hline$p$-OH benzoic & $1.66 \mathrm{a}$ & $0.73 c$ & $0.57 \mathrm{~d}$ & $0.93 b$ \\
\hline Vanilic & $4.37 \mathrm{a}$ & $2.26 \mathrm{c}$ & $2.23 b c$ & $2.74 b$ \\
\hline Syringic & n.d. & $1.33 \mathrm{a}$ & $0.76 b$ & n.d. \\
\hline$p$-Coumaric & $1.54 \mathrm{~b}$ & $0.73 \mathrm{c}$ & $0.47 \mathrm{~d}$ & $3.45 \mathrm{a}$ \\
\hline Ferulic & $7.94 b$ & $7.74 b$ & $4.68 \mathrm{c}$ & $15.76 \mathrm{a}$ \\
\hline Sinapic & $2.93 b$ & $2.00 \mathrm{bc}$ & $0.96 \mathrm{c}$ & $6.01 \mathrm{a}$ \\
\hline \multicolumn{5}{|c|}{ Sourdough fermented bread } \\
\hline$p$-OH benzoic & $3.24 \mathrm{a}$ & $1.59 \mathrm{c}$ & $1.40 \mathrm{c}$ & $2.51 \mathrm{~b}$ \\
\hline Vanilic & $4.13 \mathrm{a}$ & $2.19 \mathrm{~b}$ & $2.49 \mathrm{~b}$ & $3.89 \mathrm{a}$ \\
\hline Syringic & n.d. & $1.43 \mathrm{a}$ & $1.12 \mathrm{a}$ & n.d. \\
\hline$p$-Coumaric & n.d. & $0.31 b$ & $0.23 b$ & $1.28 \mathrm{a}$ \\
\hline Ferulic & $0.98 \mathrm{c}$ & $4.67 b$ & $6.49 b$ & $26.59 a$ \\
\hline Sinapic & $0.87 \mathrm{~b}$ & $2.93 b$ & $2.31 \mathrm{~b}$ & $15.81 \mathrm{a}$ \\
\hline
\end{tabular}

Different letters in the same line indicate statistically significant differences $(P \leq 0.05)$, obtained by the ANOVA with Duncan test $(n=3) ; n . d$. not detected

content in flour was two-sevenfold. In general, the highest increase was found in breads produced from flours, characterised by the highest initial content of total phenolic acids. The type of fermentation had an opposite effect on spelt and rye breads and on both common wheat breads. For spelt and rye breads, sourdough fermentation favoured the accumulation of free phenolic acids contents, while this type of fermentation diminished the accumulation of free phenolic acids in breads made of common wheat. Regardless of the fermentation type, free benzoic acids were preferentially accumulated in breads, especially $p$-OH benzoic and vanillic acids (Table 5).
Table 6 Free phenolic acids content in bread in vitro hydrolysates $(\mu \mathrm{g} / \mathrm{g}$ of dry matter)

\begin{tabular}{lllll}
\hline \multicolumn{5}{c}{ Bread hydrolysate } \\
\cline { 2 - 5 } & LWF & CWF & CSF & CRF \\
\hline Yeast fermented bread & & & & \\
$p$-OH benzoic & $1.49 \mathrm{a}$ & $1.69 \mathrm{a}$ & $1.67 \mathrm{a}$ & $1.68 \mathrm{a}$ \\
Vanilic & $4.38 \mathrm{a}$ & $2.97 \mathrm{~b}$ & $3.06 \mathrm{~b}$ & $3.17 \mathrm{~b}$ \\
Syringic & n.d. & $2.03 \mathrm{a}$ & $1.21 \mathrm{~b}$ & n.d. \\
$p$-Coumaric & $1.39 \mathrm{~b}$ & $0.86 \mathrm{c}$ & $0.49 \mathrm{~d}$ & $4.38 \mathrm{a}$ \\
Ferulic & $6.94 \mathrm{c}$ & $9.77 \mathrm{~b}$ & $5.76 \mathrm{~d}$ & $19.01 \mathrm{a}$ \\
Sinapic & $2.63 \mathrm{~b}$ & $2.63 \mathrm{~b}$ & $1.55 \mathrm{c}$ & $7.12 \mathrm{a}$ \\
Sourdough fermented bread & & & \\
$p$-OH benzoic & $2.39 \mathrm{~b}$ & $2.47 \mathrm{~b}$ & $2.16 \mathrm{~b}$ & $3.52 \mathrm{a}$ \\
Vanilic & $4.64 \mathrm{~b}$ & $2.72 \mathrm{c}$ & $2.94 \mathrm{c}$ & $8.33 \mathrm{a}$ \\
Syringic & n.d. & $2.04 \mathrm{a}$ & $1.67 \mathrm{a}$ & n.d. \\
$p$-Coumaric & n.d. & $0.42 \mathrm{~b}$ & $0.42 \mathrm{~b}$ & $1.9 \mathrm{a}$ \\
Ferulic & $0.88 \mathrm{~d}$ & $5.53 \mathrm{c}$ & $7.24 \mathrm{~b}$ & $32.58 \mathrm{a}$ \\
Sinapic & $0.64 \mathrm{~d}$ & $3.43 \mathrm{~b}$ & $2.97 \mathrm{c}$ & $17.08 \mathrm{a}$ \\
\hline
\end{tabular}

Different letters in the same line indicate statistically significant differences $(P \leq 0.05)$, obtained by the ANOVA with Duncan test $(n=3) ; n . d$. not detected

After in vitro digestion of prepared breads, the determined content of free phenolic acids varied from $8.55 \mu \mathrm{g} / \mathrm{g}$ DM in the sourdough fermented LWF bread sample to $63.4 \mu \mathrm{g} / \mathrm{g}$ DM in the sourdough fermented rye bread sample (Fig. 1). These values were from three to ninefold higher than in initial flours and simultaneously in three (from four) hydrolysates of CWF, spelt and rye breads ca. $30 \%$ higher than in corresponding breads. Only hydrolysates of both LWF breads showed a similar content of free phenolic acids as in corresponding breads. Taking into account the composition of used flours, the highest overall 
increase was observed in the content of $p$-OH benzoic and vanillic acids (Table 6). This was especially visible in rye bread hydrolysates, in which the final concentration of these acids exceeded the total initial value in flour.

The results of this study showed that breads and their hydrolysates are more abundant in the content of free phenolic acids, then respective flours (Fig. 1). However, the final content of these compounds in bread is the resultant of simultaneous processes of their release from cell walls, decomposition by native flour and microflora enzymes, thermal decomposition during baking and repeated binding by surrounding carbohydrates and proteins.

The main cause of the increase in the content of free phenolic acids is the activity of phenolic acid esterases during the fermentation stage. This activity was confirmed in selected lactic acid bacteria (LAB) and yeast strains. For example, Hole et al. [41] demonstrated that $L$. acidophilus LA-5, L. johnsonii LA1 and L. reuteri SD2112 strains can increase the free phenolic acid contents in oat (from 4.13 to $109.42 \mu \mathrm{g} / \mathrm{g} \mathrm{DM}$ ) and barley grain (from 2.55 to $69.91 \mu \mathrm{g} / \mathrm{g}$ DM) samples. Similarly, Ripari et al. [23] demonstrated that selected combinations of L. hammesii DSM 16381 with two strains of the L. plantarum (LM01 and PM4) effectively reduced the content of bound ferulic acid in wheat sourdough (in some samples, bound ferulic acid was almost completely liberated into free and conjugated forms). Native cereal grain also exhibits feruloyl esterase activity [42].

In turn, the decrease in concentration of free phenolic acids proceeds through their enzymatic and thermal degradation and by physical and chemical bonding. Liberated ferulic, $p$-coumaric and caffeic acids are toxic for Gram-positive bacteria under acidic conditions [13, 43, 44]. However, some LABs, particularly L. plantarum and L. brevis $[45,46]$, have a high tolerance to phenolic acids. This resistance is explained by the ability of LABs to convert phenolic acids to metabolites of reduced activity [23]. For example, ferulic acid is reduced to dihydroferulic acid and then decarboxylated to 4-vinyl-quaiacol, or decarboxylated and reduced to 4-ethyl-quaiacol [47]. In these transformations, a crucial role is the ability of a microbial strain to produce phenolic acid decarboxylase. Such activity was found in diverse fungi, yeast and bacteria (more details in Bhuiya et al. [48]). According to Ripari et al. [23], the use in wheat sourdough preparation of combinations of L. hammesii DSM 16381 with selected strains of $L$. plantarum results in efficient conversion of ferulic acid into vinyl- and ethyl-derivatives.

Another possible reason for the loss of liberated phenolic acids is their heat-liability. Ferulic acid, like other cinnamic acids, under heat treatment decarboxylates to produce ringsubstituted styrenes/vinylbenzenes [49]. Complete decomposition of ferulic and sinapic acids occurs at approx. $175^{\circ} \mathrm{C}$ [50, 51]. Liazid et al. [51] determined, that the greater the number of hydroxylic-type substituents, and the smaller the number of metoxylic-type substituents, the easier it is for degradation of phenolic acid to take place. Since bread crumb can reach maximally $100{ }^{\circ} \mathrm{C}$ during baking, phenolic acids can be degraded only in crust. However, other authors found that decomposition of phenolic acids can occur at lower temperatures. Tanchev et al. [52] recorded thermal degradation of gallic and protocatechuic acids at temperatures of $101-121^{\circ} \mathrm{C}$, at a solution $\mathrm{pH}$ in the range of $3-5$. This suggests the possibility of higher thermal phenolic acid degradation in sourdough breads.

Apart from enzymatic and thermal degradation, free phenolic acids may also be redistributed and repeatedly bound through covalent or non-covalent bonds by components of dough and bread [53-57]. Phenolic acids can be covalently bound with proteins [57], non-covalently entrapped in the hydrophobic core of polysaccharides (mainly amylose) helices $[58,59]$ or covalently bound with starch molecules through the esterification of three hydroxyl groups from a glucose unit [60]. Bound phenolic compounds are more resistant to extraction. According to Fares et al. [55] and Menga et al. [61] free $p-\mathrm{OH}$ benzoic acid is primarily susceptible to binding during cereal grain processing.

\section{Changes of antioxidative capacity from flour, through bread to bread hydrolysate}

The results of antioxidative capacity are presented in Fig. 2 . In general, the values of the DPPH assays were lower than ORAC assays and varied from 1.02 to $14.44 \mu \mathrm{M}$ TE/g DM in the case of DPPH assay and from 6.11 to $34.77 \mu \mathrm{M}$ TE/g DM for the ORAC assay. Both assays showed that rye flour, rye breads and rye digests had the highest antioxidative capacity, reaching the values of 7.92, 11.37-14.44, and 10.72-6.25 $\mu \mathrm{M}$ TE/g DM in DPPH assay, and of 11.72, 23.10-30.40, and 34.77-29.65 $\mu \mathrm{M}$ TE/g DM in the ORAC assay, respectively. The impact of the type of fermentation was relatively little visible among breads analysed using the DPPH assay, while in the ORAC assay, all breads prepared with the use of sourdoughs had a higher antioxidative capacity than variants using yeast only. Comparing breads and their digests, an opposite effect was in both assays. In the DPPH assay, all bread hydrolysates showed diminished antioxidative capacity, while in the ORAC assay almost all bread hydrolysates showed higher antioxidative capacity. The correlation coefficient between ORAC values and free phenolic acids the coefficients varied from $r=0.73(P \leq 0.05)$ to $r=0.96(P \leq 0.05)$.

The levels of antioxidative capacity values in ORAC and DPPH assays found in current study are close to those previously mentioned by Michalska et al. [62], Yu et al. [63] and Yu and Beta [64]. In all studies, the results of the ORAC assay are clearly higher than for the DPPH assay. For example, white wheat bread made with yeast has an 


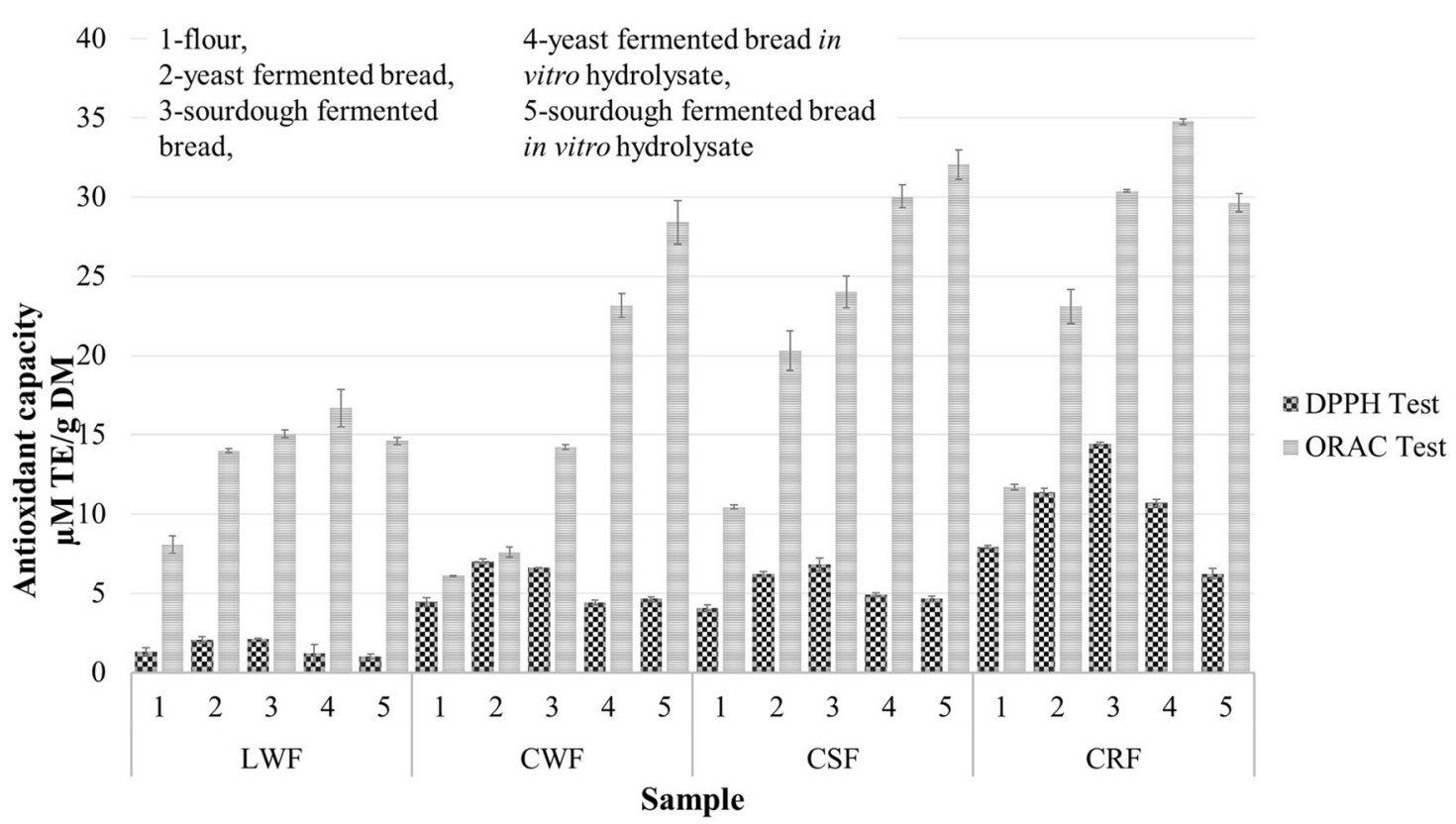

Fig. 2 Antioxidant capacity of flours, breads, and bread hydrolysates

antioxidant capacity from ca. $2 \mu \mathrm{M}$ TE/g in DPPH assay [65] to ca. $50 \mu \mathrm{M}$ TE/g in ORAC assay [66]. Similarly, Yu et al. [63] determined approx. 10-20-fold higher values of antioxidant capacity of wheat bread extract in the ORAC assay than in the DPPH assay. The determined differences may be a result of the distinct mechanisms of these assays. For ORAC, hydrogen atom transfer (HAT) mechanism occurs, while DPPH proceeds by single electron transfer (SET) [67]. It seems that the HAT mechanism predominates for flour, bread and bread digestion.

\section{Conclusions}

The wholemeal flours used in the current study exhibited a relatively low level of total and free phenolic acids. In all cases, breads were more abundant in free phenolic acids than in corresponding flour. However, the final content of these compounds is the result of simultaneous processes of their release and decomposition by native flour and/or microflora esterases and decarboxylases, thermal decomposition and repeated binding by surrounding chemicals. The overall increase of free phenolic acids determined in all samples indicated the prevalence of cell wall degradation processes. In general, free benzoic acids were preferentially accumulated in all breads. The additional increase of free phenolic acid contents in bread hydrolysates showed that digestion with $\alpha$-amylase, pepsin and pancreatin enzymes favours the solubilisation of phenolic acids bound by proteins, polysaccharides or other bread compounds. The content of free phenolic acids positively correlated $(r>0.73)$ with the antioxidative capacity of extracts measured in the ORAC assay. In contrast, the results of the DPPH assay were not related to the final concentration of phenolic acids.

It should be noted that the impact of the fermentation type on the content of free phenolic acids was not consistent. This indicates that there are additional crucial factors determining the final results, such as flour quality indices, initial total content of phenolic acids, activity of native enzymes, etc.

\section{Compliance with ethical standards}

Conflict of interest The authors declare that they have no conflict of interest.

Compliance with ethics requirements This article does not contain any studies with animal or human subjects.

Open Access This article is distributed under the terms of the Creative Commons Attribution 4.0 International License (http://creativeco mmons.org/licenses/by/4.0/), which permits unrestricted use, distribution, and reproduction in any medium, provided you give appropriate credit to the original author(s) and the source, provide a link to the Creative Commons license, and indicate if changes were made.

\section{References}

1. Angelino D, Cossu M, Marti A et al (2017) Bioaccessibility and bioavailability of phenolic compounds in bread: a review. Food Funct 8:2386-2393. https://doi.org/10.1039/c7fo00574a 
2. Bates B, Lennox A, Bates C, Swan G (2011) National diet and nutrition survey: headline results from years 1 and 2 (combined) of the rolling programme (2008/2009-2009/10)

3. O'Connor A (2012) An overview of the role of bread in the uk diet. Nutr Bull 37:193-212. https://doi.org/10.111 1/j.1467-3010.2012.01975.x

4. Piwowar A (2016) Spożycie podstawowych produktów pochodzenia roślinnego i zwierzęcego w Polsce w latach 2000-2012. Handel Wewnętrzny 1:94-103

5. Konopka I, Tańska M, Faron A, Czaplicki S (2014) Release of free ferulic acid and changes in antioxidant properties during the wheat and rye bread making process. Food Sci Biotechnol 23:831-840. https://doi.org/10.1007/s10068-014-0112-6

6. Shewry PR, Hey S (2015) Do "ancient" wheat species differ from modern bread wheat in their contents of bioactive components? J Cereal Sci 65:236-243. https://doi.org/10.1016/j.jcs.2015.07.014

7. Stuper-Szablewska K, Kurasiak-Popowska D, Nawracała J, Perkowski J (2019) Quantitative profile of phenolic acids and antioxidant activity of wheat grain exposed to stress. Eur Food Res Technol. https://doi.org/10.1007/s00217-019-03262-8

8. Challacombe CA, Abdel-Aal ESM, Seetharaman K, Duizer LM (2012) Influence of phenolic acid content on sensory perception of bread and crackers made from red or white wheat. J Cereal Sci 56:181-188. https://doi.org/10.1016/j.jcs.2012.03.006

9. Scalbert A, Williamson G (2000) Chocolate: modern science investigates an ancient medicine. J Med Food 3:121-125. https ://doi.org/10.1089/109662000416311

10. Andersson AAM, Dimberg L, Åman P, Landberg R (2014) Recent findings on certain bioactive components in whole grain wheat and rye. J Cereal Sci 59:294-311. https://doi. org/10.1016/j.jcs.2014.01.003

11. Saibabu V, Fatima Z, Khan LA, Hameed S (2015) Therapeutic potential of dietary phenolic acids. Adv Pharmacol Sci 2015:110. https://doi.org/10.1155/2015/823539

12. Holst B, Williamson G (2008) Nutrients and phytochemicals: from bioavailability to bioefficacy beyond antioxidants. Curr Opin Biotechnol 19:73-82. https://doi.org/10.1016/j.copbi o.2008.03.003

13. El-Seedi HR, El-Said AMA, Khalifa SAM et al (2012) Biosynthesis, natural sources, dietary intake, pharmacokinetic properties, and biological activities of hydroxycinnamic acids. J Agric Food Chem 60:10877-10895. https://doi.org/10.1021/jf301807g

14. Gani A, Wani SM, Masoodi FA (2012) Whole-grain cereal bioactive compounds and their health benefits: a review. J Food Process Technol 3:146-156. https://doi.org/10.4172/2157-7110.1000146

15. Kern SM, Bennett RN, Mellon FA et al (2003) Absorption of hydroxycinnamates in humans after high-bran cereal consumption. J Agric Food Chem 51:6050-6055. https://doi.org/10.1021/ jf0302299

16. Lafay S, Gil-Izquierdo A (2008) Bioavailability of phenolic acids. Phytochem Rev 7:301-311. https://doi.org/10.1007/s1110 1-007-9077-x

17. Van Craeyveld V, Holopainen U, Selinheimo E et al (2009) Extensive dry ball milling of wheat and rye bran leads to in situ production of arabinoxylan oligosaccharides through nanoscale fragmentation. J Agric Food Chem 57:8467-8473. https://doi.org/10.1021/ jf901870r

18. Wang T, He F, Chen G (2014) Improving bioaccessibility and bioavailability of phenolic compounds in cereal grains through processing technologies: a concise review. J Funct Foods 7:101-111. https://doi.org/10.1016/j.jff.2014.01.033

19. Katina K, Liukkonen KH, Kaukovirta-Norja A et al (2007) Fermentation-induced changes in the nutritional value of native or germinated rye. J Cereal Sci 46:348-355. https://doi. org/10.1016/j.jcs.2007.07.006
20. Anson NM, Aura A-M, Selinheimo E et al (2011) Bioprocessing of wheat bran in whole wheat bread increases the bioavailability of phenolic acids in men and exerts antiinflammatory effects ex vivo. J Nutr 141:137-143. https://doi.org/10.3945/jn.110.12772 0

21. Turner AL, Shewry PR, Lovegrove A, Spencer JPE (2015) Release of covalently bound hydroxycinnamate, ferulic acid, from wholegrain. Proc Nutr Soc 74:E113. https://doi.org/10.1017/S0029 665115001287

22. Koistinen VM, Mattila O, Katina K et al (2018) Metabolic profiling of sourdough fermented wheat and rye bread. Sci Rep 8:5684. https://doi.org/10.1038/s41598-018-24149-w

23. Ripari V, Bai Y, Gänzle MG (2019) Metabolism of phenolic acids in whole wheat and rye malt sourdoughs. Food Microbiol 77:4351. https://doi.org/10.1016/j.fm.2018.08.009

24. Delgado-Andrade C, Conde-Aguilera JA, Haro A et al (2010) A combined procedure to evaluate the global antioxidant response of bread. J Cereal Sci 52:239-246. https://doi.org/10.1016/j. jcs.2010.05.013

25. PN-EN ISO 712:2012 (2012) Cereal grains and cereal preparations - determination of moisture-appeal method

26. ICC standard number: 104/1 I (1990) (1990) Determination of ash in cereals and cereal products. International Association for Cereal Science and Technology, Vienna

27. PN-EN ISO 3093:2010 (2010) Wheat, rye and flours obtained from them, durum wheat and semolina-determination of falling number using the Hagberg-Perten method

28. PN-EN ISO 7937:2016 (2016) Cereal grains and cereal preparations-determination of stickiness of flour-method using an amylograph

29. PN-EN ISO 21415-2:2015 (2015) Wheat and wheat flour. Gluten content. Part 2. Determination of wet gluten and gluten index by mechanical means

30. Minekus M, Alminger M, Alvito P et al (2014) A standardised static in vitro digestion method suitable for food - an international consensus. Food Funct 5:1113-1124. https://doi.org/10.1039/ c3fo60702j

31. Skrajda-Brdak M, Konopka I, Tańska M, Sulewska H (2018) Phenolic nutrient composition and grain morphology of winter spelt wheat (Triticum aestivum ssp. spelta) cultivated in Poland. Qual Assur Saf Crop Foods 10:285-295. https://doi.org/10.3920/ QAS2018.1267

32. Konopka I, Grabiński J, Skrajda M et al (2017) Variation of wheat grain lipid fraction and its antioxidative status under the impact of delayed sowing. J Cereal Sci 76:56-63. https://doi.org/10.1016/j. jcs.2017.05.013

33. Huang D, Ou B, Hampsch-Woodill M et al (2002) High-throughput assay of oxygen radical absorbance capacity (ORAC) using a multichannel liquid handling system coupled with a microplate fluorescence reader in 96-well format. J Agric Food Chem 50:4437-4444. https://doi.org/10.1021/jf0201529

34. Li L, Shewry PR, Ward JL (2008) Phenolic acids in wheat varieties in the HEALTHGRAIN diversity screen. J Agric Food Chem 56:9732-9739. https://doi.org/10.1021/jf801069s

35. Nyström L, Lampi AM, Andersson AAM et al (2008) Phytochemicals and dietary fiber components in rye varieties in the HEALTHGRAIN diversity screen. J Agric Food Chem 56:97589766. https://doi.org/10.1021/jf801065r

36. Belobrajdic DP, Bird AR (2013) The potential role of phytochemicals in wholegrain cereals for the prevention of type- 2 diabetes. Nutr J 12:62-73. https://doi.org/10.1186/1475-2891-12-62

37. Kurasiak-Popowska D, Stuper-Szablewska K, Nawracała J et al (2016) Phenolic acid content in wheat grain (\{Triticum $\}$ spp) of different genotypes. Rev Fac Cie Agrar 48:1-7 
38. Michalska A, Ceglinska A, Amarowicz R et al (2007) Antioxidant contents and antioxidative properties of traditional rye breads. J Agric Food Chem 55:734-740. https://doi.org/10.1021/jf062425w

39. Konopka I, Tańska M, Faron A et al (2012) Comparison of the phenolic compounds, carotenoids and tocochromanols content in wheat grain under organic and mineral fertilization regimes. Molecules 17:12341-12356. https://doi.org/10.3390/molecules1 71012341

40. Martini D, Taddei F, Ciccoritti R et al (2015) Variation of total antioxidant activity and of phenolic acid, total phenolics and yellow coloured pigments in durum wheat (Triticum turgidum $\mathrm{L}$. var. durum) as a function of genotype, crop year and growing area. $\mathbf{J}$ Cereal Sci 65:175-185. https://doi.org/10.1016/j.jcs.2015.06.012

41. Hole AS, Rud I, Grimmer S et al (2012) Improved bioavailability of dietary phenolic acids in whole grain barley and oat groat following fermentation with probiotic Lactobacillus acidophilus, Lactobacillus johnsonii, and Lactobacillus reuteri. J Agric Food Chem 60:6369-6375. https://doi.org/10.1021/jf300410h

42. Dynkowska WM, Cyran MR, Ceglińska A (2015) Soluble and cell wall-bound phenolic acids and ferulic acid dehydrodimers in rye flour and five bread model systems: insight into mechanisms of improved availability. J Sci Food Agric 95:1103-1115. https:// doi.org/10.1002/jsfa.7007

43. Tran NP, Gury J, Dartois V et al (2008) Phenolic acid-mediated regulation of the padC gene, encoding the phenolic acid decarboxylase of Bacillus subtilisa. J Bacteriol 190:3213-3224. https ://doi.org/10.1128/JB.01936-07

44. Rivas-Sendra A, Landete JM, Alcántara C, Zúñiga M (2011) Response of Lactobacillus casei BL23 to phenolic compounds. J Appl Microbiol 111:1473-1481. https://doi.org/10.111 1/j.1365-2672.2011.05160.x

45. Rodriguez-Palacios A, Staempfli HR, Duffield T, Weese JS (2009) Isolation of bovine intestinal Lactobacillus plantarum and Pediococcus acidilactici with inhibitory activity against Escherichia coli O157 and F5. J Appl Microbiol 106:393-401. https://doi.org /10.1111/j.1365-2672.2008.03959.x

46. Curiel JA, Rodríguez H, Landete JM et al (2010) Ability of Lactobacillus brevis strains to degrade food phenolic acids. Food Chem 120:225-229. https://doi.org/10.1016/j.foodchem.2009.10.012

47. Van Beek S, Priest FG (2000) Decarboxylation of substituted cinnamic acids by lactic acid bacteria isolated during malt whisky fermentation. Appl Environ Microbiol 66:5322-5328. https://doi. org/10.1128/AEM.66.12.5322-5328.2000

48. Bhuiya MW, Lee SG, Jez JM, Yu O (2015) Structure and mechanism of ferulic acid decarboxylase (FDC1) from Saccharomyces cerevisiae. Appl Environ Microbiol. https://doi.org/10.1128/ AEM.00762-15

49. Maga JA, Katz I (1978) Simple phenol and phenolic compounds in food flavor. C R C Crit Rev Food Sci Nutr 10:323-372. https:// doi.org/10.1080/10408397809527255

50. Fiddler W, Parker WE, Wasserman AE, Doerr RC (1967) Thermal decomposition of ferulic acid. J Agric Food Chem 15:757-761. https://doi.org/10.1021/jf60153a003

51. Liazid A, Palma M, Brigui J, Barroso CG (2007) Investigation on phenolic compounds stability during microwave-assisted extraction. J Chromatogr A 1140:29-34. https://doi.org/10.1016/j.chrom a.2006.11.040

52. Tanchev S, Ioncheva N, Genov N, Malchev E (1979) Kinetics of the thermal degradation of some phenolic acids. Food Nahrung 23:863-866. https://doi.org/10.1002/food.19790230903

53. Hemery YM, Anson NM, Havenaar R et al (2010) Dry-fractionation of wheat bran increases the bioaccessibility of phenolic acids in breads made from processed bran fractions. Food Res Int 43:1429-1438. https://doi.org/10.1016/j.foodres.2010.04.013
54. Vaher M, Matso K, Levandi T et al (2010) Phenolic compounds and the antioxidant activity of the bran, flour and whole grain of different wheat varieties. Proced Chem 2:76-82. https://doi. org/10.1016/j.proche.2009.12.013

55. Fares C, Platani C, Baiano A, Menga V (2010) Effect of processing and cooking on phenolic acid profile and antioxidant capacity of durum wheat pasta enriched with debranning fractions of wheat. Food Chem 119:1023-1029. https://doi.org/10.1016/j. foodchem.2009.08.006

56. Laddomada B, Caretto S, Mita G (2015) Wheat bran phenolic acids: bioavailability and stability in whole wheat-based foods. Molecules 20:15666-15685. https://doi.org/10.3390/molecules2 00915666

57. Xu J, Wang W, Li Y (2019) Dough properties, bread quality, and associated interactions with added phenolic compounds: a review. J Funct Foods 52:629-639. https://doi.org/10.1016/j. jff.2018.11.052

58. Kandil A, Li J, Vasanthan T, Bressler DC (2012) Phenolic acids in some cereal grains and their inhibitory effect on starch liquefaction and saccharification. J Agric Food Chem 60:8444-8449. https ://doi.org/10.1021/jf3000482

59. Van Hung P, Phat NH, Phi NTL (2013) Physicochemical properties and antioxidant capacity of debranched starch-ferulic acid complexes. Starch 65:382-389. https://doi.org/10.1002/star.20120 0168

60. Obiro WC, Sinha Ray S, Emmambux MN (2012) V-amylose structural characteristics, methods of preparation, significance, and potential applications. Food Rev Int 28:412-438. https://doi. org/10.1080/87559129.2012.660718

61. Menga V, Fares C, Troccoli A et al (2010) Effects of genotype, location and baking on the phenolic content and some antioxidant properties of cereal species. Int J Food Sci Technol 45:7-16. https ://doi.org/10.1111/j.1365-2621.2009.02072.x

62. Michalska A, Amigo-Benavent M, Zielinski H, del Castillo MD (2008) Effect of bread making on formation of Maillard reaction products contributing to the overall antioxidant activity of rye bread. J Cereal Sci 48:123-132. https://doi.org/10.1016/j. jes.2007.08.012

63. Yu L, Nanguet A-L, Beta T (2013) Comparison of antioxidant properties of refined and whole wheat flour and bread. Antioxidants 2:370-383. https://doi.org/10.3390/antiox2040370

64. Yu L, Beta T (2015) Identification and antioxidant properties of phenolic compounds during production of bread from purple wheat grains. Molecules 20:15525-15549. https://doi. org/10.3390/molecules200915525

65. Chlopicka J, Pasko P, Gorinstein S et al (2012) Total phenolic and total flavonoid content, antioxidant activity and sensory evaluation of pseudocereal breads. LWT Food Sci Technol 46:548-555. https ://doi.org/10.1016/j.lwt.2011.11.009

66. Liyana-Pathirana CM, Shahidi F (2007) The antioxidant potential of milling fractions from breadwheat and durum. J Cereal Sci 45:238-247. https://doi.org/10.1016/j.jcs.2006.08.007

67. Koroleva O, Torkova A, Nikolaev I et al (2014) Evaluation of the antiradical properties of phenolic acids. Int J Mol Sci 15:1635116380. https://doi.org/10.3390/ijms150916351

Publisher's Note Springer Nature remains neutral with regard to jurisdictional claims in published maps and institutional affiliations. 